\title{
Poverty Alleviation And Microcredit In Sub-Saharan Africa
}

\author{
Wali I. Mondal, National University, USA
}

\begin{abstract}
Sub-Saharan Africa (SSA) continues to be the most poverty- stricken region of the world. Concerns about poverty in SSA and poverty reduction efforts for this region have been documented extensively. The most recent effort aimed at global poverty reduction is known as the Millennium Development Goals (MDG). The first of the eight goals of the MDG calls for eradication of extreme poverty and hunger with a target to "halve, between 1990 and 2015, the proportion of people whose income is less than \$1 a day." An evaluation of this goal in 2005 reveals that SSA countries have failed to reduce the incidence of extreme poverty while other regions of the world have achieved success in this effort. This paper analyzes the incidence of extreme poverty in SSA in relation to the socio-economic infrastructure of the region, its land tenure system, and particularly the growth of microcredit and microentrepreneurship. Using primary data, the paper analyzes the growth of microcredit which operates through 297 microfinance institutes in 34 countries of the region. Extensive use of microfinancing has shown to reduce extreme poverty among the users of microcredit. Use of microcredit at the grassroots level creates a class of microentrepreneur with characteristics similar to the model of entrepreneurship developed by Schumpeter. The study concludes that there is a prospect for the growth of microentrepreneurship in at least 13 countries of SSA allowing for new employment opportunities, savings among borrowers, and reduction of extreme poverty.
\end{abstract}

Keywords: Poverty, Sub-Saharan Africa, Millennium Development Goals, extreme poverty, microcredit, microentrepreneurship.

\section{INTRODUCTION}<smiles>[LiH]</smiles>

ub-Saharan Africa (SSA) consisting of 48 countries (Appendix A) is the only region of the world where the number of people living in abject poverty continues to grow. According to the United Nations Industrial Development Organization (UNIDO), those living in absolute poverty in the region (earning less than $\$ 1$ a day), rose from $42 \%$ to $47 \%$ from 1981 to 2001 , while absolute poverty dropped from $40 \%$ to $21 \%$ in the world as a whole (http://news.bbc.co.uk/2/hi/africa/3910719.stm). Concerns about poverty in SSA and poverty reduction efforts for this region have been documented extensively; however, the use and adoption of models of microcredit has not been tested in this region. In recent years, many countries of the region have adopted some form of microcredit model with a goal to reducing poverty. The microcredit operation in these countries is conducted through the Microfinance Institutes (MFIs) - a financial institution similar to a commercial bank with the exception that lending and borrowing are conducted with the sole objective of making credit accessible to the poor who cannot obtain a loan from a conventional financial institute because of the inability to provide a collateral. Many countries that have adopted one or more varieties of microcredit model have achieved success in reducing the incidence of poverty among the borrowers, and in addition, have been able to create a class of microentrepreneurs who operate with a limited amount of physical capital. The objective of this paper is to analyze the microcredit operation of the SSA countries and to evaluate the effectiveness of this operation in reducing poverty through creating a class of microentrepreneurs. 


\section{POVERTY ALLEVIATION IN SUB-SAHARAN AFRICA: SUMMITS AND MILLENNIUM DEVELOPMENT GOALS}

Poverty alleviation is the common and overriding objective of the developing world. During the past two decades, world leaders met in several summits and deliberated on measures to reduce the incidence of poverty. In February 1997, more than 2900 attendees including heads of governments from 137 countries gathered in the Microcredit Summit in Washington D.C. to devise strategies for reducing poverty worldwide. The historic Campaign ended with a resolution to "reach 100 million of the world's poorest families, especially the women of those families, with credit for self-employment and other financial and business services by the year 2005" (Microcredit Summit Campaign 2002). The best known summit to date was held in September 2000 where ostensibly the largest gathering of world leaders representing 189 countries including 147 heads of government adopted the United Nations Millennium Declaration, committing their nations to a new global partnership to reduce extreme poverty and setting out a series of time-bound goals with target deadline of 2015. These goals have become known as the Millennium Development Goals (MDGs) for addressing extreme poverty in its many dimensions. While income was considered as the major factor of poverty, other factors such as hunger, disease, lack of adequate shelter, gender equality, education, and environmental sustainability were also included in these goals. The eight MDGs are listed below:

1. Eradicate extreme poverty and hunger

2. Achieve universal primary education

3. Promote gender equality and empower women

4. $\quad$ Reduce child mortality

5. Improve maternal health

6. Combat HIV/AIDS, malaria and other diseases

7. Ensure environmental sustainability

8. Develop a Global Partnership for Development.

Each of the above eight goals have one or more targets attached to it with a total of 18 targets for the 8 goals. For the purpose of this paper, goal 1 has direct relationship with microcredit operation, although goals 3 and 7 are often associated with goal 1 as positive externalities. Goal 1 has two targets:

- $\quad$ Halve, between 1990 and 2015, the proportion of people whose income is less than $\$ 1$ a day

- Halve, between 1990 and 2015, the proportion of people who suffer from hunger

In 2005, countries that participated in developing the MDGs engaged in an evaluation of the goals. The bleakest prosperity was noted for the Sub-Saharan African countries. The following evaluation summarizes the existing extreme poverty in the region and the progress made as of 2005:

"Africa south of the Sahara has the highest proportion of people living in poverty, with nearly half its population around 300 million people - living below the international poverty line of USD 1 a day. In the 1990s, the number of poor in the region increased by one-quarter. The number of impoverished people in sub-Saharan Africa is expected to rise from 315 million in 1999 to 404 million by 2015. If current trends continue, Africa will be the only region where the number of poor people in 2015 will be higher than in 1990." (http://www.africangreenrevolution.com/en/green_revolution/africas_predicament/poverty/index.html) In analyzing poverty in the Sub-Saharan Africa, Sachs, et al (2004) concludes that "Large parts of Sub-Saharan Africa are stuck in a poverty trap". Poverty trap, according to this analysis, refers to the existence of extreme poverty in this region leading to low savings, low investment productivity, poor health, persistent diseases, and lack of infrastructure thus crippling the possibilities of economic growth. The World Bank Global Monitoring Report 2005 (World Bank 2005) takes issues with the Sachs hypothesis; however, the report concludes "The persistence of poverty across countries is consistent with the hypothesis" ( $\mathrm{p} 28$ ). The Global Monitoring Report analyzed the existing state of poverty and future prospects of the SSA countries in comparison to other low-income countries. In particular, the report analyzed the prospect of poverty alleviation as set by the MDG by the year 2015. The analysis suggested that only the SSA countries were "seriously off track" towards the path of fulfilling MDG target 1 of goal 1. Figure 1 captures the evaluation of the World Bank 2005 Report. 


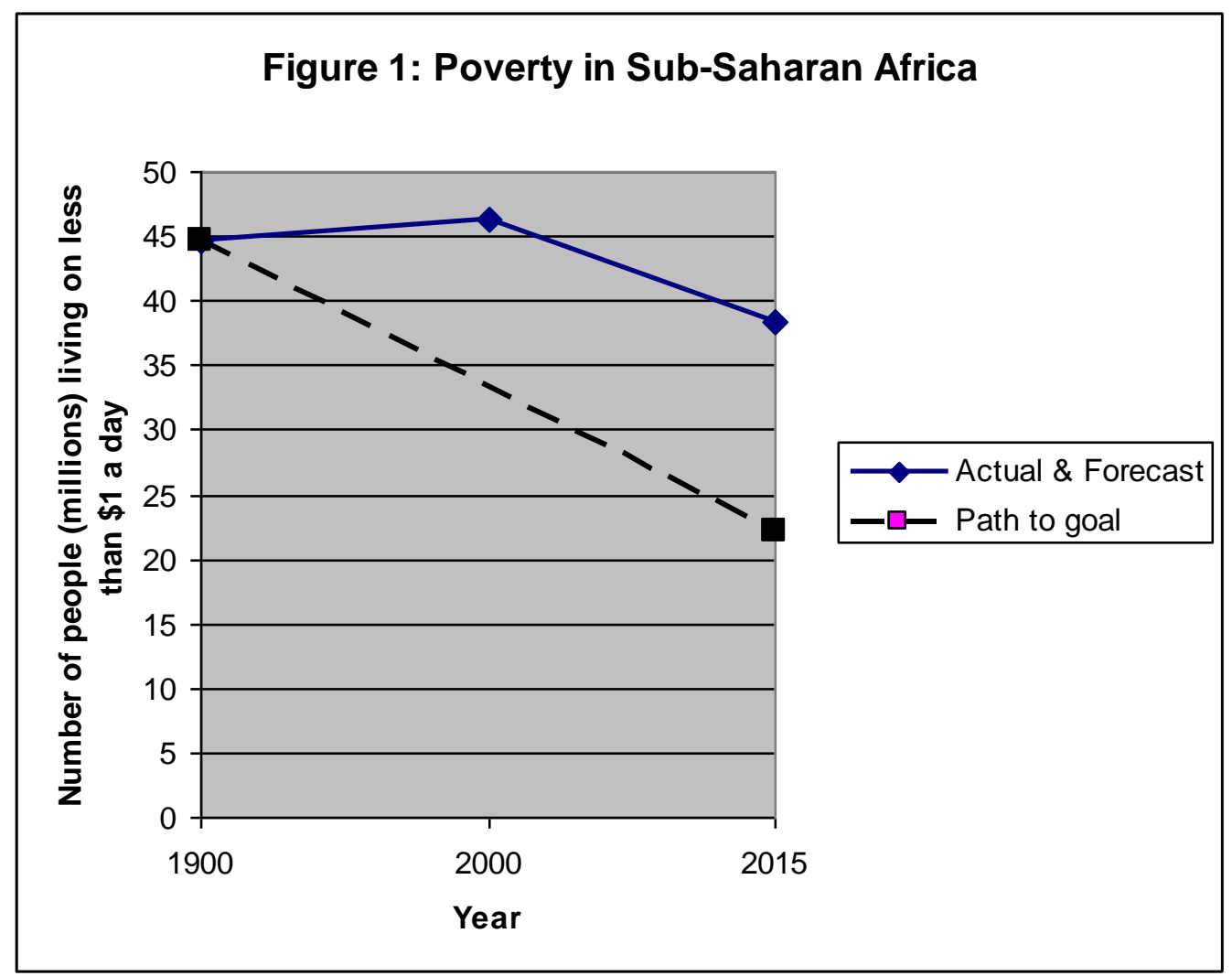

Source: World Monitoring Report 2005; adapted by permission.

As Figure 1 shows, the MDG target of halving poverty in SSA countries by 2015 required that 22.3 million people lived on less than \$1 a day; however, the projected number of living on less than \$1 a day by 2015 is 38.4 million. Other studies on poverty alleviation in SSA countries confirm this projection.

The World Bank 2005 Report also concluded that the SSA countries required a "high rate of growth" in order to fulfill MDG of poverty reduction. As Table 1 shows almost half of the 28 countries of the sample required a rate of growth of over 6 percent. The World Bank staff estimated that the weighted average required growth in per capita GDP for the region was 5.2 percent a year; however, most of Africa does not grow at or near that level.

Table 1: Required Rate of Growth of selected SSA Countries for achieving income poverty MDG

\begin{tabular}{|l|c|c|c|c|}
\hline $\begin{array}{c}\text { Required growth of } \\
\text { per capita GDP, } \\
\text { 2005-15 }\end{array}$ & Number of Countries & $\begin{array}{c}\text { Population, 2000 } \\
\text { (millions) }\end{array}$ & $\begin{array}{c}\text { Share of Sub } \\
\text { Saharan population } \\
\text { (percent) }\end{array}$ & $\begin{array}{c}\text { Share of Sub } \\
\text { Saharan GDP, 2000 } \\
\text { (percent) }\end{array}$ \\
\hline Less than 2 percent & 1 & 9.5 & 1 & 2 \\
\hline 2-3 percent & 4 & 124.5 & 19 & 52 \\
\hline 3-4 percent & 2 & 20.2 & 3 & 1 \\
\hline 4-6 percent & 4 & 44.4 & 7 & 5 \\
\hline More than 6 percent & 17 & 315.4 & 48 & 27 \\
\hline Total & 28 & 514 & 78 & 87 \\
\hline
\end{tabular}

Source: World Monitoring Report 2005; adapted by permission. 


\section{MICROCREDIT AND POVERTY ALLEVIATION: THE ORIGINAL MODEL}

The concept of collateral free microcredit originated in Bangladesh around the beginning of the $20^{\text {th }}$ century when Rabindranath Tagore founded the Kaligram Krishi (Agricultural) Bank in Patishar village in the district of Naogaon in 1905 (Mondal, 2002). Tagore represented a landlord family and introduced the group-based microcredit program with a goal to help the desperately poor peasants who were unable to pay the rental on the land they cultivated. The essence of microcredit program, as envisioned by Tagore, is the absence of physical collateral. Microcredit is defined as a system of credit delivery and savings mobilizing scheme especially designed to meet the unique financial requirement of the poor. The financing scheme allows the recipients to improve the status of their living through access to additional capital without collateral. A borrower of microcredit must belong to a group to qualify for a loan. The original microcredit model required that a group of five individuals apply for a loan on behalf of one member. The group guaranteed repayment of a loan offered to one member at a time. Once a group member has paid off a loan, another member of the group may qualify for a new loan or a repeat loan may be granted to a non-defaulting client. The original model has gone through many transformations. In most countries, microfinance clients are typically self-employed and low-income entrepreneurs in both urban and rural areas. A typical microloan to a group in Bangladesh ranges from Taka 4,000 to Taka 50,000 (U.S. \$ 57 - \$714), although individual loans of Tk $400,000(\$ 5,715)$ are not uncommon. Loan amounts and profiles of borrowers are similar in other countries. Clients are often traders, street vendors, small farmers, service providers, artisans and small producers. Usually their activities provide a stable source of income (often from more than one activity). In addition to financial intermediation, many MFIs provide social intermediation services such as group formation, development of selfconfidence, and training in financial literacy and management capabilities among members of a group. Thus the definition of microfinance often includes both financial intermediation and social intermediation. The size of an initial loan or the microcredit varies from MFI to MFI. A variety of loan products is available and more are being developed for individuals and businesses.

Many studies suggest that since inception, microcredit programs have been able to reduce the incidence of extreme poverty. A World Bank study found that percentage of Grameen Bank, Bangladesh borrowers living in extreme poverty was reduced by 70 percent within 4.2 years of joining the group-based microcredit program (Latifee, 2000). Research conducted by the Consultative Group for the Poor in Indonesia, found that microcredit borrowers increased their incomes by 12.9 percent compared to 3.0 percent by the incomes of non-clients. (http://www.sbp.org.pk/reports/quarterly/FY05/first/Special_2.pdf).

The microfinancing approach has evolved as an economic development tool intended to benefit lowincome women and men including the self-employed. MFIs can be non-governmental organizations (NGOs), savings and loan cooperatives, credit unions, government bank, commercial banks, or non-bank financial institutions. The recovery rate of microcredit in most countries exceeds 90 percent which compares to a much lower recovery rate for conventional loans. For example, China faces a serious problem of nonperforming loans (NPL). Most estimates suggest that the NPL in China is around 50 per cent and in Bangladesh, the recovery rate of conventional loan is 63 percent. Today, in addition to group based lending, microcredit is offered to individual borrowers with or without collateral. Although the primary goal of microcredit operation is poverty alleviation, providing assistance to an existing microenterprise and developing the microentrepreneur class is seen as a secondary goal in many countries.

\section{MICROCREDIT AND MICROENTREPRENEURSHIP}

The growth of MFIs and particularly their near perfect loan recovery rate has been accompanied by the development of a variety of loan products offered by individual MFIs. As a result, the number of borrowers increased manifold which in turn led to the development of new loan products. Borrowers of microcredit do not fall into the same category and in most instances, MFIs make a distinction of borrowers and offer differentiated loan products to different groups. For example, ASA (pronounced "Asha") an NGO in Bangladesh, offers two types of loans: small loan and small business loan. The size of the initial small loan is quite small and is comparable to similar microloans offered by other MFIs in the country. It is offered to landless women who do not own any asset and are defined to be very poor. On the other hand, the small business loan is significantly larger in size and is offered to an existing business. The existing business may need the additional capital to either expand its operation 
or to buy equipment for modernizing its product or to explore new markets for an existing product. Other resourceful MFIs also differentiate between borrowers along the same general line as ASA. The borrowers of MFIs, therefore, may be classified as:

\section{- $\quad$ Microborrowers}

- Microentrepreneurs

The microborrowers demonstrate a willingness and ability to generate a steady flow of income through conventional sources such as trading or paddy husking. There is no significant risk involved in the income generating activities of the microborrowers. Their labor is the predominant input, which is supplemented by a stock of capital in the form of a microcredit. The microborrower's ability to repay the loan is evaluated jointly with other members of the group. A microentrepreneur usually owns a microenterprise and is engaged in innovating new ways of doing business or initiating changes in the production function, exploring market opportunities for his product and, ultimately changing the culture of doing business.

The term "entrepreneur" was first introduced in the Mercantilist age by Richard Cantillon (1680-1734). Schumpeter (1950) noted "Cantillon's work, which is usually, though not quite correctly described as the first systematic treatise on economics, introduced the term "entrepreneur". Cantillon defined an entrepreneur as the agent who buys means of production at certain prices in order to combine them into a product that he is going to sell at prices that are uncertain at the moment at which he commits himself to his costs". (pp 253-54). The idea thus developed by Cantillon was incorporated into Say's Treatise on Political Economy (1821). Say defined an entrepreneur as an agent who combines other resources into a "productive organism". He also used the term to indicate shifting of resources from a lower productive state to a higher productive state. It is important to note that Say did not incorporate the element of risk in his analysis of entrepreneurship although Cantillon alluded to it. Later, John Stuart Mill developed the concept further and associated entrepreneurship with activities involving risk and profit (Mill, 1871).

Although Mill incorporated risk in his analysis of profit and linked it to entrepreneurship, he, in fact was using the terms "entrepreneur" and "capitalist" synonymously. It appears that during most of the later nineteenth century, the two terms were used synonymously. Joseph Schumpeter is the first economist who distinguished between an entrepreneur and a capitalist (Schumpeter, 1939, 1950). According to him, assumption of risk involving innovation is the role of the entrepreneur, while assumption of risk involving potential for profit is the role of a capitalist. Both an entrepreneur and a capitalist undertake risk; but their domains are separate. Individuals who own business and take risk with their capital in pursuit of profit, but do not innovate, are capitalists. There are individuals who take risk by introducing a new product, adopting a new production process, creating new markets, introducing new technology or creating a new economic organization. Schumpeter referred to these individuals as "entrepreneurs" who belong to a "distinct sociological class". According to him, the process of discovery and innovation modifies the past and creates new opportunities for the creation of wealth in the future. This is what Schumpeter described as the process of "creative destruction".

According to Schumpeter, "the function of entrepreneur is to reform or revolutionize the pattern of production by exploiting an innovation or, more generally, an untried technological possibility for producing a new commodity or producing an old one in a new way, by opening up a new source of supply of materials or a new outlet for products, by reorganizing an industry..." He went on to attribute innovation as the business activity that brings about a new production function as a result of one or more of the following five economic activities:

1. introduction of a new good

2. adoption of new inputs to produce a new good or the previously produced good

3. introduction of new technology

4. opening of a new market; and

5. creating a new economic organization.

At the heart of Schumpeter's analysis is innovation, which is accompanied by risk assumed by an entrepreneur. Figure 2 captures Schumpeter's model of entrepreneurship. 


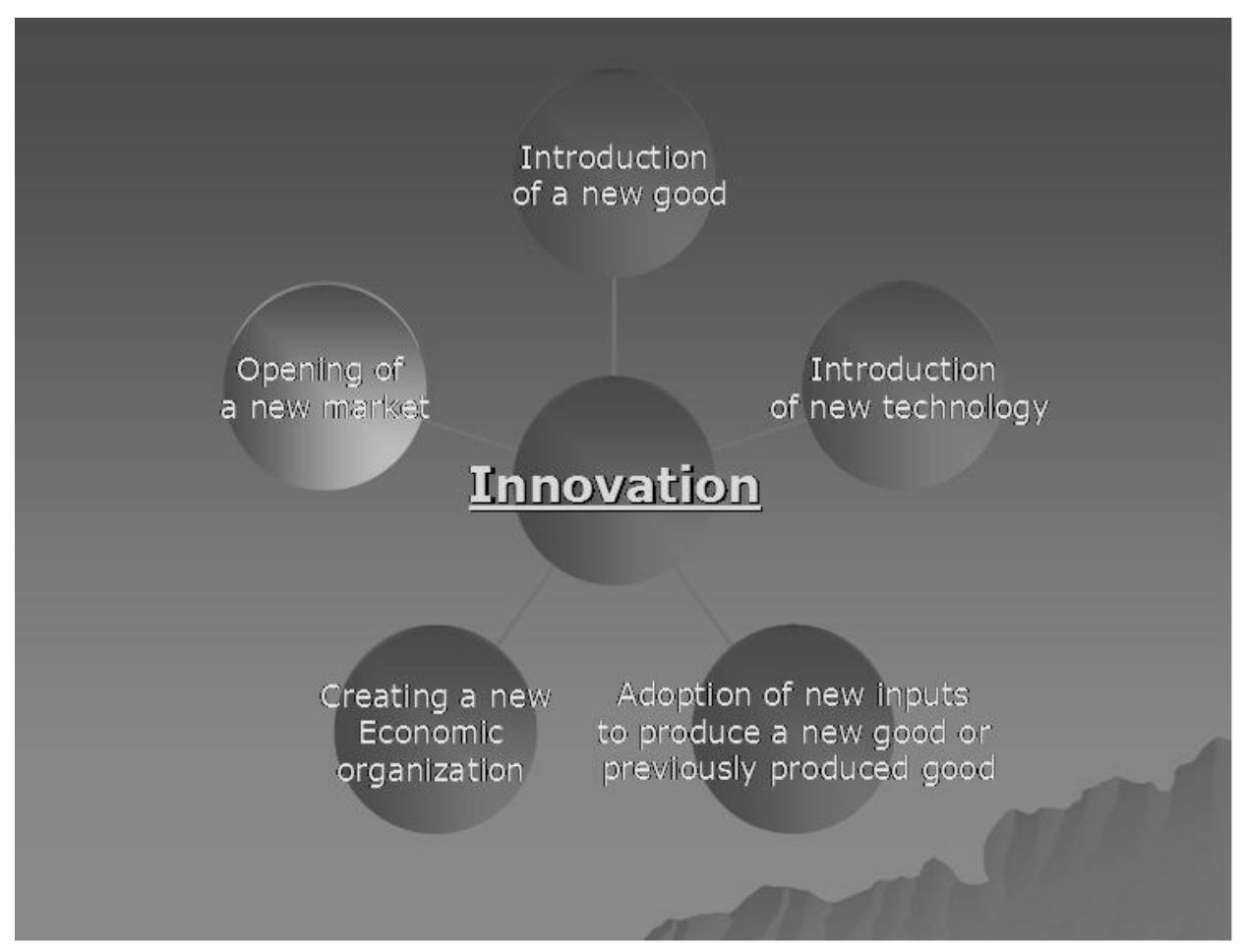

Figure 2: Schumpeter's model of entrepreneurship

Schumpeter's theory of entrepreneurship stimulated extensive writing on the subject. Numerous studies have supported various sets of personality characteristics based on certain assumptions about behavior where sets of criteria, traits and personal principles and characteristics provide different types of insight. An approach now gaining more popularity explains entrepreneurship by combining economic, personal, and sociological variables. Personal characteristics, such as the need for achievement, risk-taking propensity, locus of control, Beliefs about wealth and material gain, and business growth are related to a person's predisposition toward business leadership (Gartner, 1990, McDaniel, 2002). A belief that a person can influence his or her personal destiny and locus of control distinguishes entrepreneurs from the general population. The microentrepreneurs possess the traits and characteristics of the "distinct sociological class" described by Schumpeter.

There have been significant discussions on the role of an entrepreneur in developed and developing economies after the work of Schumpeter, particularly by Sweezy (1943), Leontief (1937), Angell (1941), Wright (1947), Lange (1943), Rostow (1948) and McDaniel (2002). In reality, Schumpeter's model works through the transformation of a production function. Using microcredit, microentrepreneurs of many developing countries, notably Bangladesh, have been able to transform their existing businesses to other organizational forms which use intermediate technology or advanced technologies.

\section{MICROCREDIT OPERATION IN SUB-SAHARAN AFRICA}

Microcredit arrived in Sub-Saharan Africa relatively late. Using country data, we trace the adoption of microcredit programs by the region mostly after 2000. At the present time, 34 out of 48 countries of the region have some type of microcredit programs. There are a total of 297 MFIs operating in this region. There are 22 MFIs operating in Uganda, the largest number in any one country of the region. Kenya, Benin and Senegal also have good number of MFIs operating at 22, 19 and 17 respectively. As noted earlier, SSA countries suffer from extreme form of poverty. Approximately 50 per cent of the population of the region still lives below the internationally defined 
poverty line of less than $\$ 1$ a day. We find that 94 MFIs (31 per cent of the total) operating in 27 countries have targeted population below the poverty line as their clients. The average loan offered by the MFIs is rather small and ranges from US $\$ 55$ to $\$ 6,912$. The size of the loan offered by the MFIs an important factor in evaluating the success of the microcredit program and the potential growth of microentrepreneurship in the SSA countries. Table 2 summarizes the loans offered by the MFIs in SSA countries.

Table 2: Loan profiles of MFIs in SSA countries

\begin{tabular}{|l|c|c|c|}
\hline \multicolumn{1}{|c|}{ Average Loan (US \$) } & Number of MMFIs & Number of countries & Target for poverty alleviation \\
\hline Less than $\$ 100$ & 36 & 6 & Yes \\
\hline$\$ 101-\$ 1000$ & 227 & 34 & Yes \\
\hline$\$ 1001-\$ 5000$ & 32 & 12 & Yes \\
\hline Over $\$ 5000$ & 2 & 1 & N.A. \\
\hline
\end{tabular}

The classification of MFIs on the basis of average loan was made with a view to studying the growth prospects of microentrepreneurship. A study by Mondal (2002) analyzed the growth of microentrepreneurship in Bangladesh. Although the socio-economic condition of Bangladesh is different from that of the SSA countries, many countries of the region are comparable to Bangladesh in terms of income per capita, and the path to microentrepreneurship follows the same economic profile. Mondal found that smaller loans of less than $\$ 100$ were likely to be consumed and unpaid. Loans in the range of $\$ 101-\$ 1,000$ allow borrowers to improve their economic condition with a stable source of income in the trading sector. These loans are classified as microloans and are typically offered to non-entrepreneurial purposes. Loans in the range of $\$ 1,001-\$ 5,000$ provide the borrowers the ability to assume risks and innovate.

The loan profiles of the 297 MFIs of SSA countries indicate that there is a prospect for the growth of microentrepreneurship in at least 13 countries of the region where the size of the loan may allow the borrowers to assume a certain degree of risk. However, the region as a whole lacks the fundamentals of macroeconomic policies consisting of fiscal policy, composition of public spending, monetary policy, consistency of macroeconomic policies, public sector governance, transparency in monetary and financial institutions, and trade regime for any program of investment. Table 3 compares the fundamental macroeconomic policies of the SSA countries with those of other regions of the world.

Table 3: Macroeconomic Policies in Sub-Saharan Africa and other low income countries (percentage of countries)

\begin{tabular}{|c|c|c|c|c|c|c|c|}
\hline Region/Rating & $\begin{array}{l}\text { Fiscal } \\
\text { policy }\end{array}$ & $\begin{array}{c}\text { Composition } \\
\text { of public } \\
\text { spending }\end{array}$ & $\begin{array}{c}\text { Monetary } \\
\text { Policy }\end{array}$ & $\begin{array}{c}\text { Consistency } \\
\text { of Macro } \\
\text { Policies }\end{array}$ & $\begin{array}{c}\text { Public } \\
\text { sector } \\
\text { Governance }\end{array}$ & $\begin{array}{c}\text { Governance and } \\
\text { transparency in } \\
\text { monetary and } \\
\text { financial } \\
\text { institutions } \\
\end{array}$ & $\begin{array}{c}\text { Trade } \\
\text { Regime }\end{array}$ \\
\hline $\begin{array}{l}\text { Sub Saharan } \\
\text { Africa }\end{array}$ & \multirow[b]{2}{*}{42} & \multirow[b]{2}{*}{68} & \multirow[b]{2}{*}{17} & \multirow[b]{2}{*}{30} & \multirow[b]{2}{*}{46} & \multirow[b]{2}{*}{30} & \multirow[b]{2}{*}{14} \\
\hline Unsatisfactory & & & & & & & \\
\hline Good & 22 & 3 & 72 & 46 & 14 & 52 & 73 \\
\hline $\begin{array}{l}\text { Other low } \\
\text { income } \\
\text { countries }\end{array}$ & \multirow[b]{2}{*}{19} & \multirow{3}{*}{$\begin{array}{l}57 \\
10\end{array}$} & \multirow{3}{*}{$\frac{7}{74}$} & \multirow{3}{*}{$\frac{14}{55}$} & \multirow{3}{*}{$\frac{26}{14}$} & \multirow{3}{*}{$\frac{7}{63}$} & \multirow{3}{*}{$\begin{array}{c}5 \\
86\end{array}$} \\
\hline Unsatisfactory & & & & & & & \\
\hline Good & 48 & & & & & & \\
\hline
\end{tabular}

Source: World Monitoring Report 2005; adapted by permission.

Studies, Sahn and Younger (2004), Collier and Gunning (1999), and Gladwin (1991) also indicate the absence of several preconditions of growth and development. The most important of these preconditions is the lack of stable government in the region. In our study, we found that only 3 out of the 34 countries having some form of microcredit program had democratically elected governments in the region for the period of this study. In addition to 
the absence of constitutional government in the region, all studies suggest that poverty alleviation in SSA countries need to be preceded or accompanied by reforms of social and economic institutions. Poverty alleviation and economic development in Sub-Saharan Africa requires empowerment of private-sector producers. State-owned land tenure system is still prevalent in most countries of SSA, and producers must sell their products through state controlled marketing boards (Mbeki 2005). Because of the weak macroeconomic policies and state-owned land tenure system, SSA countries continue to suffer from a number of major disadvantages relative to other regions of the world. A disproportionately large number of landlocked countries in the region are dependent on trade with their immediate neighbors. Agricultural production of the region is vulnerable to the vagaries of nature including periodic droughts. The growth of microcredit operation in the region, particularly, the growth of microentrepreneurship is expected to ease many of these conditions; however, macroeconomic reforms of the region appear to be the key to the success of microcredit and microentrepreneurship program of the Sub-Saharan African countries.

\section{SUMMARY AND CONCLUSIONS}

Sub-Saharan Africa is the only region of the world where the number of people living in abject poverty continues to grow. Concerns about poverty in Africa, and particularly Sub-Saharan Africa, and poverty reduction efforts for this region have been documented extensively; however, the use and adoption of models of microcredit has not been tested in this region. In recent years, many countries of the region have adopted some form of microcredit model with a goal to reducing poverty. Poverty alleviation and economic development in Sub-Saharan Africa requires empowerment of private-sector producers. State-owned land tenure system is still prevalent in most countries of SSA, and producers must sell their products through state controlled marketing boards. In this study, we analyzed the loan profiles of 297 MFIs of SSA countries. The results indicate that there is a prospect for the growth of microentrepreneurship in at least 13 countries of the region where the size of the loan may allow the borrowers to assume a certain degree of risk. The microcredit operation in SSA can be a successful experience if reforms accompany the growth of the microcredit programs paving a way for the growth of microentrepreneurship.

\section{REFERENCES}

1. Angell, J.W. 1941. Investment Business Cycles. New York and London: McGraw-Hill.

2. Collier, Paul, and Jan Willem Gunning. 1997. "Explaining Economic Performance." CSAE Working Paper 97/02. Oxford University, Centre for the Study of African Economies, Oxford

3. Commission for Africa. 2005. Our Common Interest: Report of the Commission for Africa. London

4. Gartner, William B. 1990. "Who Are We Talking About When We Talk About Entrepreneurship?" Journal of Business Ventures, January: 15-28

5. Gladwin, C.H (ed). 1991. Structural Adjustment and African Women Farmers. Gainesville, FL: University of Florida Press.

6. $\quad$ Lange, O. 1943. “A Note on Innovations.” Review of Economic Statistics, February 1943: 19-25.

7. Latifee, H.I. 2000.Microcredit and poverty reduction; Experiences of Grameen operation in Asia.

8. Dhaka, Bangladesh: Grameen Trust

9. Mbeki, Moeletsi (2005). Perpetuating Poverty in Sub-Saharan Africa. How African political elites undermine entrepreneurship and economic development. London: International Policy Press.

10. McDaniel, Bruce. 2002. Entrepreneurship and Innovation: An Economic Approach. Armonk, New York: M.E. Sharpe.

11. Microcredit Summit +5. 2002. http://www.microcreditsummit.org

12. Mills, John Stuart. 1848. Principles of Political Economy. London: Macmillan Press.

13. Mondal, Wali I. 2002. Microcredit and Microentrepreneurship. Collateral Free Loan at Work in Bangladesh. Dhaka, Bangladesh: Academic Press.

14. Mondal, Wali I and Ruth Ann Tune. 1993. "Replicating the Grameen Bank in North America: The Good Faith Fund Experience." In Abu N.M. Wahid, ed. The Grameen Bank

15. Rostow, W.W. 1948. British Economy of the Nineteenth Century. New York: Oxford University Press.

16. Sachs, Jeffrey, John W. McArthur, Guido Schmidt-Traub, Margaret Kruk, Chan-drika Bahadur, Michael Faye, and Gordon McCord. 2004. "Ending Africa's Poverty Trap."Brooking Papers on Economic Activity 1. Washington, D.C.: Brookings Institution. 
17. Sahn, David E. and Stephen D. Younger. 2004. "Growth and Poverty Reduction in Sub-Saharan Africa: Macroeconomic Adjustment and Beyond”. Journal of African Studies, Vol. 13, AERC, Supplement, pp i66-i95.

18. Say, J.B. 1821. A Treatise on Political Economy. (Transaled by C.R. Princep). Boston: Wells and Lilly (originally published in 1803).

19. Schumpeter, Joseph A. 1950. Capitalism, Socialism and Democracy. New York: Harper and Sons.

20. 1939. Business Cycles: A Theoretical, Historical, and Statistical Analysis of the Capitalist Process. New York: McGraw-Hill.

21. _ 1936. The Theory of Economic Development: An Inquiry into Profits, Capital Credit, Interest and the Business Cycle. Cambridge, MA: Harvard University Press.

22. Sweezy, P.M. 1943. "Professor Schumpeter's Theory of Innovation". Review of Economic Statistics. February 1943: 93-96.

23. World Bank. 2005. Global Monitoring Report 2005. The International Bank for Reconstruction and Development, Washington, D.C.

24. http://news.bbc.co.uk/2/hi/africa/3910719.stm

25. http://www.africangreenrevolution.com/en/green revolution/africas_predicament/poverty/index.html

26. $\quad$ http://www.sbp.org.pk/reports/quarterly/FY05/first/Special_2.pdf

\section{APPENDIX A: COUNTRIES OF SUB-SAHARAN AFRICA}

\begin{tabular}{|l|l|l|l|}
\hline 1 & Angola & 25 & Liberia \\
\hline 2 & Benin & 26 & Madagascar \\
\hline 3 & Botswana & 27 & Malawi \\
\hline 4 & Burkina Faso & 28 & Mali \\
\hline 5 & Burundi & 29 & Mauritania \\
\hline 6 & Cameroon & 30 & Mauritius \\
\hline 7 & Cape Verde & 31 & Mozambique \\
\hline 8 & Central African Republic & 32 & Namibia \\
\hline 9 & Chad & 33 & Niger \\
\hline 10 & Comoros & 34 & Nigeria \\
\hline 11 & Congo, Democratic Republic & 35 & Rwanda \\
\hline 12 & Congo, Republic & 36 & Sao Tome and Principe \\
\hline 13 & Ivory Coast & 37 & Senegal \\
\hline 14 & Djibouti & 38 & Seychelles \\
\hline 15 & Equatorial Guinea & 39 & Sierra Leone \\
\hline 16 & Eritrea & 40 & Somalia \\
\hline 17 & Ethiopia & 41 & South Africa \\
\hline 18 & Gabon & 42 & Sudan \\
\hline 19 & Gambia & 43 & Swaziland \\
\hline 20 & Ghana & 44 & Tanzania \\
\hline 21 & Guinea & 45 & Togo \\
\hline 22 & Guinea-Bissau & 46 & Uganda \\
\hline 23 & Kenya & 47 & Zambia \\
\hline 24 & Lesotho & 48 & Zimbabwe \\
\hline
\end{tabular}

\section{AUTHOR INFORMATION}

Dr. Wali I. Mondal is a Professor of Business at National University in La Jolla California, where he also served as Interim Dean during March 2007 to June 2008. Mondal received his Ph.D. from the Ohio State University and has been a full time faculty over 26 years. During 1993-96, he served as the Chair of the Department of Accounting, Economics and Business Education at Henderson State University. He has published a scholarly book titled Microcredit and Microentrepreneurship: Collateral Free Loan at Work in Bangladesh (Academic Press, 2002) and over 70 papers and book chapters in refereed journals. Professor Mondal is the founding President and Conference Chair of the American Society of Business and Behavioral Sciences (ASBBS www.asbbs.org ). He is also the Editor-in-Chief of the Journal of Business and Behavioral Sciences. 
NOTES 